\title{
Gender influence on antioxidant capacity and oxidative damage in saliva of children with autism spectrum disorder: a preliminary study
}

\author{
Influência do gênero de crianças com transtorno do espectro do autismo na \\ capacidade antioxidante e danos oxidativos na saliva: estudo preliminar
}

\author{
Matheus Morcela De SOUZA ${ }^{a}$ (D), João Victor Soares RODRIGUESa ${ }^{(D)}$, \\ Maria Eduarda CABRERIZO GONÇALVES ${ }^{a}$ (1) , Ana Carolina Polanowski ROSSATOa ${ }^{(1)}$,

 \\ Ana Cláudia de Melo Stevanato NAKAMUNE ${ }^{\text {** }}$ (D) \\ a UNESP - Universidade Estadual Paulista, Faculdade de Odontologia de Araçatuba, Araçatuba, SP, Brasil \\ b UNESP - Universidade Estadual Paulista, Faculdade de Odontologia de Araçatuba, Centro de Assistência \\ Odontológica à Pessoa com Deficiência (CAOE), Araçatuba, SP, Brasil
}

\begin{abstract}
How to cite: De Souza MM, Rodrigues JVS, Cabrerizo Gonçalves ME, Rossato ACP, Voms Stein MCR, Poli MCF, Theodoro LH, Nakamune ACMS. Gender influence on antioxidant capacity and oxidative damage in saliva of children with autism spectrum disorder: a preliminary study. Rev Odontol UNESP. 2021;50:e20210057. https://doi.org/10.1590/1807-2577.05721
\end{abstract}

\begin{abstract}
Resumo
Introdução: 0 autismo é uma desordem neurológica complexa de causas multifatoriais, que compromete habilidades físicas, psicológicas, emocionais e sociais, podendo dificultar os cuidados com a saúde bucal. A saliva, que pode ser coletada de forma fácil e não invasiva, vem sendo utilizada para diagnóstico e triagem de várias condições e patologias. A capacidade antioxidante total nesse fluido está reduzida em crianças com cárie e tem sido investigada como possível marcador para essa doença, mas são escassas as informações sobre antioxidantes na saliva de crianças com o Transtorno do Espectro do Autismo (TEA). Objetivo: 0 objetivo desse estudo preliminar foi verificar a influência do gênero na diferença da capacidade antioxidante e no dano oxidativo proteico, na saliva de crianças com TEA. Material e método: A saliva total foi obtida por aspiração, entre 8:00 e 11:00 horas, de 12 meninas e 12 meninos com idades entre 5 e 15 anos, com diagnóstico prévio de TEA. A capacidade antioxidante total, o ácido úrico, a concentração total de proteínas e o dano oxidativo proteico foram analisados por espectrofotometria. Os valores de média e desvio padrão foram testados quanto à normalidade (Shapiro-Wilk teste) e comparados com o teste Mann Whitney. 0 nível de significância foi estabelecido em $5 \%$. Resultado: Nenhuma diferença significativa entre os grupos foi observada, nos parâmetros analisados $(\mathrm{P}>0,05)$. Conclusão: Com base nos resultados obtidos, concluímos que o gênero não influencia nos níveis de marcadores do estresse oxidativo na saliva de crianças com TEA.
\end{abstract}

Descritores: Transtorno do espectro autista; gênero; saliva; antioxidantes; estresse oxidativo.

\begin{abstract}
Introduction: Autism is a complex neurological disorder with multifactorial causes, which compromises physical, psychological, emotional and social skills. This disorder also impairs dental care and patient oral health. Saliva can be easily obtained using a non-invasive technique and has been used in the diagnosis and screening of many pathologies. Total antioxidant capacity of saliva is reduced in the presence of caries in children and has been studied as a possible marker for autism. However, data on salivary antioxidants in children with autism spectrum disorder (ASD) is scarce. Objective: This preliminary study evaluated the existence of gender influence on non-enzymatic antioxidant capacity and protein oxidative damage in the saliva of children with this disorder. Our hypothesis is that there are gender differences in these biochemical parameters in children with austim. Material and method: Whole saliva samples were collected by aspiration between 8:00-11:00 am from 12 girls and 12 boys aged 5 to 15 years, with previous diagnosis for this disorder. Total antioxidant capacity, uric acid, protein concentration and oxidative damage to
\end{abstract}


proteins were analyzed by spectrophotometry. Values were presented as mean \pm standard deviation and tested for adherence to normality (Shapiro-Wilk test). The data were then compared using the MannWhitney test, considering a 5\% significance level. Result: There was no significant difference between groups for all analyzed parameters $(\mathrm{P}>0.05)$. Conclusion: Based on the results obtained, we concluded that gender does not influence the levels of oxidative stress markers in the saliva of children with ASD.

Descriptors: Autism spectrum disorder; gender; saliva; antioxidant; oxidative stress.

\section{INTRODUCTION}

Autism Spectrum Disorder (ASD) is a neurodevelopmental condition that affects 10 out of every 1,000 children worldwide. Impairment of communication and social interaction, shown by withdrawal and lack of interest in other people, repetitive or restricted behaviors and/or interests are common in these circumstances, as well as intellectual deficit and epilepsy ${ }^{1,2}$. All these behaviors and alterations can complicate dental care in children and adults with ASD ${ }^{3}$.

Reduced release of neurotransmitters in the cerebellum, prefrontal and temporal cortices are associated with several behavioral changes presented by patients with ASD ${ }^{4,5}$. Besides, an increased oxidative stress due to reduced antioxidant defense ${ }^{6}$ and consequently greater damage to proteins are identified as causes of neurodegeneration in these individuals 7 .

Studies from our research group observed alterations in oxidative stress markers in the saliva of patients with other neurological diseases, such as cerebral palsy ${ }^{8}$ and microcephaly ${ }^{9}$. Other authors observed a reduction in the total antioxidant capacity (TAC) in the saliva of individuals with ASD in comparison to the neurotypical group, associated with poor oral hygiene ${ }^{10}$. In neurotypical children, changes in the redox state, with a prevalence of antioxidants, were also described in the presence of caries ${ }^{11}$ and the magnitude of these variations seems to be associated with the severity of the injury ${ }^{12}$.

There are several conditions that cause oral problems in individuals with ASD, such as eating habits, chewing difficulties, continuous use of medication and poor oral hygiene ${ }^{13-15}$. The study of possible markers of oxidative stress associated with caries in ASD patients depends primarily on comprehensive knowledge of the characteristics of the saliva of these individuals, but information about the influence of gender on these parameters in the saliva of these individuals is scarce. Therefore, the aim of this preliminary study was to evaluate the existence of gender influence on non-enzymatic antioxidant capacity and protein oxidative damage in the saliva of patients with ASD, aged between 5 and 15 years. Our hypothesis is that there are gender differences in these biochemical parameters in children with ASD.

\section{MATERIAL AND METHOD}

This cross-sectional observational study is part of a larger project entitled "Evaluation of the oral condition of patients with Autism Spectrum Disorder", approved by the Research Ethics Committee of the Araçatuba School of Dentistry FOA-UNESP (CAAE: 24597019.5.0000.5420).

\section{Sample Calculation}

Values of average and standard deviation of salivary total antioxidant capacity ${ }^{8}$, were used for the sample calculation, with the aid of the Open Epi (Atlanta, Georgia, USA). Considering 95\% for the confidence interval and $80 \%$ for the test power, the sample number (n) was 12 (twelve)/group. 


\section{Selection of Patients}

Among the patients diagnosed with ASD treated in an outpatient clinic by the Dental Assistance Center for People with Disabilities (CAOE) of the São Paulo University (UNESP), School of Dentistry, Araçatuba, 15 females and 15 males aged between 5 and 15 years were invited to participate in the study. Inclusion's criteria were previous diagnosis for ASD; patients undergoing treatment at the CAOE and in good health and oral hygiene, certified by a dentist from the Center's team. Exclusion's criteria were non-collaborating patients, need for sedation, unstable health, carriers of blood disorders, edentulous patients, patients supplemented with vitamins two months prior to collection, and those whose legal guardians did not sign the free and informed consent form.

\section{Collection of Saliva Samples}

Whole saliva samples were obtained between 8:00 and 11:00 am, on a pre-scheduled date for the patients follow-up appointment at the CAOE. Two hours prior to collection, food intake, toothpaste or rinsing solutions were not allowed. Mouth cleaning was done 2 hours before the procedure using water and a brush.

During sample collection, patients remained seated in a room with pleasant temperature and light while the fluid was aspirated from the mouth floor into a sterile, sealed bottle in an ice bath, with the aid of a suction device for a maximum of 10 minutes $^{8}$. Saliva was centrifuged at 10,000 g (Centrifuge $5810 \mathrm{R}$, Eppendorf, Hamburg, Germany) at $4^{\circ} \mathrm{C}$ for $10 \mathrm{~min}$ to remove cells and reduce turbidity ${ }^{16}$. The supernatant was fractionated and stored at $-80^{\circ} \mathrm{C}$ until the time of analysis.

\section{Protein Concentration}

Protein concentration was evaluated by Lowry's method, as described by Hartree ${ }^{17}$ using bovine serum albumin (Sigma Aldrich, Saint Louis, Mussouri, U.S.A.) as standard curve, ranging from 0.1 to $1.0 \mathrm{mg} / \mathrm{mL}$. Absorbance was determined at $660 \mathrm{~nm}$ wavelength in a microplate reader (Power Wave 340-Biotek, Winooski, Vermont, USA).

\section{Total Non-Enzymatic Antioxidant Capacity}

The FRAP assay ${ }^{18}$ was used with a concentration of 0.2 to $3.0 \mathrm{nmol} / \mathrm{L}$ ferrous sulfate (Synth, Diadema, São Paulo, Brazil) as a standard curve and absorbance was estimated at $595 \mathrm{~nm}$ in a microplate reader.

\section{Uric Acid Concentration}

A commercial colorimetric enzymatic system with an end-point reaction (Labtest S.A., Lagoa Santa, MG, Brazil) was used, according to the manufacturer's recommendations and with the aid of a semi-automatic analyzer (BIO 2000, Bioplus, Barueri, SP, Brazil).

\section{Protein Oxidative Damage}

The oxidative damage to proteins was evaluated based on carbonylation, through an alkaline reaction with 2,4-dinitrophenylhydrazine (Sigma Aldrich, Saint Louis, Mussouri, U.S.A.) as described by Mesquita et al. ${ }^{19}$. 


\section{Statistical Analysis}

Values presented as mean \pm standard deviation were tested for adherence to normality using the Shapiro-Wilk test. To compare groups, the Mann Whitney test was adopted, considering a 5\% significance level (GraphPad Prim 8.02).

\section{RESULT}

Of the 30 patients invited to participate in the study, 24 remained, being 12 girls and 12 boys. The others were excluded for showing discomfort during saliva collection, which was interrupted and not resumed. The average ages were $9.08 \pm 2.84$ for girls and $9.17 \pm 2.98$ for boys. The minimum and maximum ages for girls were 6 and 15 years old, respectively. For boys, these values were 5 and 14 years old, respectively.

Regarding the use of medication, $50 \%$ of the girls used antipsychotics, 33\% used anticonvulsants, $25 \%$ used antidepressants and $25 \%$ used anxiolytics. In this group, $50 \%$ use an association of two or three classes of drugs. In the group of boys, $100 \%$ were medicated with antipsychotics, 33\% anticonvulsants, $25 \%$ antidepressant and $8 \%$ anxiolytic. Drug association was present in $58 \%$ of boys.

There was no significant difference between groups in values for total protein (girls: $1.075 \pm$ $0.370 \mathrm{mg} / \mathrm{mL}$; boys: $1.430 \pm 0.7480 ; \mathrm{p}=0.3259$ ), or for antioxidant defense (TAC and UA) and oxidative damage to proteins (protein carbonyl, PC) (Table 1).

Table 1. Values of total non-enzymatic antioxidant capacity (TAC), uric acid (UA) and protein carbonyl (PC) in saliva of girls and boys with autism spectrum disorder (ASD)

\begin{tabular}{cccc}
\hline Parameters & Girls $(\mathbf{n}=\mathbf{1 2})$ & Boys $(\mathbf{n}=\mathbf{1 2})$ & P value \\
\hline TAC $(\mu \mathrm{mol} / \mathrm{mg}$ protein $)$ & $0.428 \pm 0.247$ & $0.397 \pm 0.228$ & 0.7553 \\
UA $(\mu \mathrm{mol} / \mathrm{mg}$ protein $)$ & $0.0041 \pm 0.0022$ & $0.0039 \pm 0.0037$ & 0.5522 \\
PC $(\mu \mathrm{mol} / \mathrm{mg}$ protein $)$ & $0.051 \pm 0.056$ & $0.028 \pm 0.016$ & 0.7021 \\
\hline
\end{tabular}

Mean values \pm standard deviation. Mann Whitney test, significance level $5 \%$.

\section{DISCUSSION}

ASD is a complex neurological disorder with multifactorial causes which compromises physical, psychological, emotional and social skills of patients ${ }^{20}$. The preference for foods with sweeter taste and pasty consistency, poor oral hygiene due to lack of dexterity, supervision or acceptance, as well as continuous use of medications that reduce salivary flow can compromise the oral health of these individuals, increasing susceptibility to caries and gingivitis ${ }^{3,13-15}$. In addition, behavioral changes in these children can make dental care difficult, resulting in further deterioration of oral health.

Antipsychotic, antidepressant, anxiolytic and anticonvulsant medications are commonly used to minimize behavioral, social and neurological changes in these patients, providing better quality of life for them and their caregivers. The most used drug in the studied groups was antipsychotics, followed by anticonvulsants. All boys in the studied group used antipsychotics, while only half of the girls were medicated with this class of drug. The use of anticonvulsants and antidepressants was similar between girls and boys. These drug classes, which in most patients used in association, interfere with salivary flow ${ }^{14}$, therefore we chose not to determine this parameter in this preliminary study. Still, in order to normalize the oxidative stress markers results, we used total protein concentrations. For that reason, all results are expressed as a function of the amount of protein in the sample, expressed in milligrams (mg) ${ }^{8,9,11,12}$. 
Saliva can be easily obtained using a non-invasive technique and has been used in the diagnosis and screening of many pathologies. This multifunctional fluid is essential for the maintenance of oral health and homeostasis and is composed of water, electrolytes, proteins, enzymes, volatile compounds, hormones of endogenous origin and antioxidant compounds, such as uric acid (UA), glutathione, sialic acid and albumin. The individual measurement of antioxidants is very expensive and time-consuming. Thus, an alternative approach is to measure the TAC using FRAP assay to estimate UA which contributes approximately $70 \%$ to TAC of saliva and other non-enzymatic antioxidants, such as vitamins $\mathrm{C}$ and $\mathrm{E}$ and bilirubin ${ }^{21}$. Therefore, saliva also plays an important role in the control of oxidative stress, reflecting the imbalance between the generation of reactive oxygen species and the ability to scavenge such harmful substances or repair them, resulting damage through enzymatic and non-enzymatic antioxidant defense systems, in favor of the oxidants. These reactive species are produced by physiological metabolism, medication use, local and systemic pathologies and conditions ${ }^{22}$.

Recent studies have shown that in neurotypical children, caries severity has a direct effect on TAC and UA, which gradually reduces salivary oxidative damage ${ }^{12}$. In children with ASD, salivary TAC was significantly reduced in relation to their healthy counterparts ${ }^{10}$. However, studies with saliva of children with ASD are scarce, particularly those investigating the possible variations associated with gender, which was the purpose of the present study.

The absence of gender-associated differences in salivary TAC values was not observed in a study conducted on the saliva of neurotypical individuals with mean ages of $23.4 \pm 3.0$ years for the female group and $25.4 \pm 3.1$ years, for the male group ${ }^{21}$. In that case, the authors observed significantly higher TAC values in women's saliva, but they did not carry out the uric acid assay. In the present study, no gender difference was observed in UA. This TAC discrepancy may be related to changes in the composition of salivary non-enzymatic antioxidants, due to age, and needs to be further investigated using specific assays for each antioxidant. The oxidative damage to proteins was greater in the saliva of adult men than in women ${ }^{21}$, different of our results in saliva of children with ASD, but the methodology used to analyze this parameter was different. The absence of statistical differences could be associated with the sample size, suggesting an insufficient sample to determine the statistical difference, because this is a preliminary study. Therefore, other studies are being conducted by our group in order to know the redox profile in the saliva of patients with ASD, before using them as indicative of caries disease.

\section{CONCLUSION}

Within the limits of this study, it was concluded that in saliva of children with autism spectrum disorder gender does not influence the oxidative stress biomarkers evaluated in this study.

\section{ACKNOWLEDGEMENTS}

The authors would like to thank the entire Dental Assistance Center for People with Disabilities (CAOE) team for their support during this project and the Pro-Rectory of Research at Unesp for their financial support (PIBIC process 1692/2021).

\section{REFERENCES}

1. Alsehemi MA, Abousaadah MM, Sairafi RA, Jan MM. Public awareness of autism spectrum disorder. Neurosci J. 2017 Jul;22(3):213-5. PMid:28678216. 
2. Moss P, Mandy W, Howlin P. Child and adult factors related to quality of life in adults with autism. J Autism Dev Disord. 2017 Jun;47(6):1830-7. http://dx.doi.org/10.1007/s10803-017-3105-5. PMid:28343343.

3. Jaber MA. Dental caries experience, oral health status and treatment needs of dental patients with autism. J Appl Oral Sci. 2011 May-June;19(3):212-7. http://dx.doi.org/10.1590/S167877572011000300006 . PMid:21625735.

4. László A, Horváth E, Eck E, Fekete M. Serum serotonin, lactate and pyruvate levels in infantile autistic children. Clin Chim Acta. 1994 Sep;229(1-2):205-7. http://dx.doi.org/10.1016/0009-8981(94)902437. PMid:7988051.

5. Macfabe D. Autism: metabolism, mitochondria, and the microbiome. Glob Adv Health Med. 2013 Nov;2(6):52-66. http://dx.doi.org/10.7453/gahmj.2013.089. PMid:24416709.

6. Tang G, Gutierrez Rios P, Kuo SH, Akman HO, Rosoklija G, Tanji K, et al. Mitochondrial abnormalities in temporal lobe of autistic brain. Neurobiol Dis. 2013 Jun;54:349-61. http://dx.doi.org/10.1016/j.nbd.2013.01.006. PMid:23333625.

7. Esparham AE, Smith T, Belmont JM, Haden M, Wagner LE, Evans RG, et al. Nutritional and metabolic biomarkers in autism spectrum disorders: an exploratory study. Integr Med. 2015 Apr;14(2):40-53. PMid:26770138.

8. Cunha-Correia AS, Hernandes AH No, Pereira AF, Aguiar SM, Nakamune AC. Enteral nutrition feeding alters antioxidant activity in unstimulated whole saliva composition of patients with neurological disorders. Res Dev Disabil. 2014 Jun;35(6):1209-15. http://dx.doi.org/10.1016/j.ridd.2014.03.003. PMid:24685936.

9. Alves TM, Barbieri CM, Gomes MA, Araujo HC, Visquette NO, Louzada LPA, et al. Alteration on redox status in saliva of microcephaly children. Soc Dev. 2021;10(7):e40010716796. http://dx.doi.org/10.33448/rsd-v10i7.16796.

10. Rai K, Hegde AM, Jose N. Salivary antioxidants and oral health in children with autism. Arch Oral Biol. 2012 Aug;57(8):1116-20. http://dx.doi.org/10.1016/j.archoralbio.2012.03.006. PMid:22521893.

11. Silva PVD, Troiano JA, Nakamune ACMS, Pessan JP, Antoniali C. Increased activity of the antioxidants systems modulate the oxidative stress in saliva of toddlers with early childhood caries. Arch Oral Biol. 2016 Oct;70:62-6. http://dx.doi.org/10.1016/j.archoralbio.2016.06.003. PMid:27328152.

12. Araujo HC, Nakamune ACMS, Garcia WG, Pessan JP, Antoniali C. Carious lesion severity induces higher antioxidant system activity and consequently reduces oxidative damage in children's saliva. Oxid Med Cell Longev. 2020 Jan;2020:3695683. http://dx.doi.org/10.1155/2020/3695683. PMid:32089767.

13. Klein U, Nowak A. Autistic disorder- a review for the pediatric dentist. Pediatr Dent. 1998 SepOct;20(5):312-7. PMid:9803429.

14. Rekha CV, Arangannal P, Shahed H. Oral health status of children with autistic disorder in Chennai. Eur Arch Paediatr Dent. 2012 Jun;13(3):126-31. http://dx.doi.org/10.1007/BF03262858. PMid:22652209.

15. Bhandary S, Hari N. Salivary biomarker levels and oral health status of children with autistic spectrum disorders: a comparative study. Eur Arch Paediatr Dent. 2017 Apr;18(2):91-6. http://dx.doi.org/10.1007/s40368-017-0275-y. PMid:28236284.

16. Santos DR, Souza RO, Dias LB, Ribas TB, Oliveira LCF, Sumida DH, et al. The effects of storage time and temperature on the stability of salivary phosphatases, transaminases and dehydrogenase. Arch Oral Biol. 2018 Jan;85:160-5. http://dx.doi.org/10.1016/j.archoralbio.2017.10.016. PMid:29080481.

17. Hartree EF. Determination of protein: a modification of the Lowry method that gives a linear photometric response. Anal Biochem. 1972 Aug;48(2):422-7. http://dx.doi.org/10.1016/00032697(72)90094-2. PMid:4115981. 
18. Benzie IF, Strain JJ. The ferric reducing ability of plasma (FRAP) as a measure of "antioxidante power": the FRAP assay. Anal Biochem. 1996 Jul;239(1):70-6. http://dx.doi.org/10.1006/abio.1996.0292. PMid:8660627.

19. Mesquita CS, Oliveira R, Bento F, Geraldo D, Rodrigues JV, Marcos JC. Simplified 2,4dinitrophenylhydrazine spectrophotometric assay for quantification of carbonyls in oxidized proteins. Anal Biochem. 2014 Aug;458:69-71. http://dx.doi.org/10.1016/j.ab.2014.04.034. PMid:24814294

20. Rai K, Hegde AM, Jose N. Salivary antioxidants and oral health in children with autism. Arch Oral Biol. 2012 Aug;57(8):1116-20. http://dx.doi.org/10.1016/j.archoralbio.2012.03.006. PMid:22521893.

21. Baek J, Lee MG. Oxidative stress and antioxidant strategies in dermatology. Redox Rep. 2016 Jul;21(4):164-9. http://dx.doi.org/10.1179/1351000215Y.0000000015. PMid:26020527.

22. Żukowski P, Maciejczyk M, Waszkiel D. Sources of free radicals and oxidative stress in the oral cavity. Arch Oral Biol. 2018 Aug;92:8-17. http://dx.doi.org/10.1016/j.archoralbio.2018.04.018. PMid:29729478.

\section{CONFLICTS OF INTERESTS}

The authors declare no conflicts of interest.

\section{*CORRESPONDING AUTHOR}

Ana Cláudia de Melo Stevanato Nakamune, UNESP - Universidade Estadual Paulista, Faculdade de Odontologia de Araçatuba, Departamento de Ciências Básicas, Rua José Bonifácio, 1193, 16015-050 Araçatuba, SP, Brasil, e-mail: ana.nakamune@unesp.br

Received: November 3, 2021

Accepted: November 4, 2021 